\title{
薩揧國人指紋の研究
}

\author{
三 浦 正 義
}

\section{第一章 緒鍮並䃑究材料}

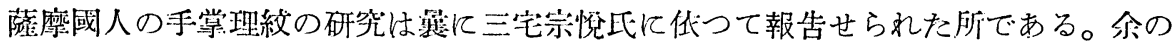
報告は同國人の指紋伤關するものであつて。先づ同國人の指紋の性質を論じ、次で本 邦諸地方人证ざに周園䍀人秝との比較を行つた。研筦材料としては三宅氏が昭和 9 年:

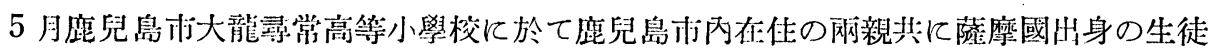
中、高學年より男 103 例、女 108 例飞就て探印せられた指紋の貸藇を受けたものであ る。兹に三宅氏に對し深琎の謝意を表する。

\section{第二章 研 究成 綪}

薩縻人男 103 例、女 108 例合計 422 手に於ける指紋式並に其頻度を舉げると第 1 表 の如くなる。即ち指紋式の種類は男性沉於ては右手 29 種、左手 33 種、左右共通なる もの 22 種男性合計 40 種、女性江於ては右手 28 種。左手 32 種左右共通なるもの 21 程 女性合計 39 種となり、此等の中男女共通なるもの 28 種で男女總計は 51 種となる。又

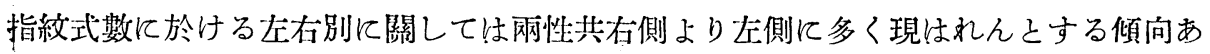
るは一般的現像に一致するが性别關しては男女畧と同數であるととは大隅人の場合 と同心く他地方人を稍趣を異㑟する。

次に此等 51 種の指紋式中に於て比較的出現率の多代表的指紋式を舉げると第 2 表の如くなる。

即ち男性飞於ては w w w w w $(19.9 \% \pm 2.78 \%)$, u u u u u $(12.9 \% \pm 2.31 \%)$, w w w w u $(8.2 \% \pm 1.91 \%)$, w u u u u $(5.3 \% \pm 1.56 \%)$, w u u w u $(5.3 \% \pm 1.56 \%)$ 等が出現率多く、女性飞 於ては u u u u u $(20.9 \% \pm 2.76 \%$, ) w w w w w $(9.2 \%$ $\pm 1.96 \%)$, w w w w u $(6.5 \% \pm 1.67 \%)$, w u u u u $(5.1 \% \pm 1.50 \%)$, w w. u. w u $(4.6 \% \pm 1.40 \%)$ 等が代表的である。

更に w w w w w と u u u u u との性别祭しては、 w w w w w は女性よ

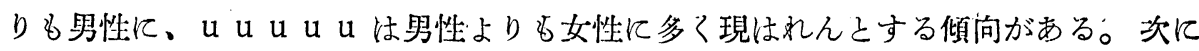


籍 1. 表 陸嘛國人に於ける指紋式とその頻度表 (1)

\begin{tabular}{|c|c|c|c|c|c|c|c|c|c|c|}
\hline \multirow{2}{*}{\multicolumn{5}{|c|}{ 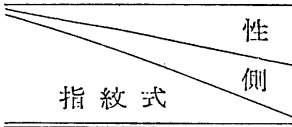 }} & \multicolumn{3}{|c|}{$\sigma^{\circ}$} & \multicolumn{3}{|c|}{ 우 } \\
\hline & & & & & $\mathrm{r}$ & 1 & $\mathrm{r}+1$ & $\mathbf{r}$ & 1 & $\mathrm{r}+1$ \\
\hline$a$ & $\mathrm{u}$ & $\mathrm{u}$ & $\mathrm{u} \quad \mathrm{v}$ & $\mathrm{u}$ & - & - & - & 一. & 3 . & 3 \\
\hline$a$ & $\mathrm{u}$ & $a$ & $\mathrm{u} \quad \mathrm{u}$ & $\mathrm{u}$ & - & 1 & 1. & - & - & - \\
\hline a & $\mathrm{u}$ & $\mathrm{u}$ & $a$ & $\mathrm{a}$ & - & - & - & 1. & - & 1. \\
\hline $\mathbf{u}$ & $a$ & $\mathrm{u}$ & u & $\mathrm{u}$ & - & 1. & 1. & - & - & - \\
\hline $\mathrm{u}$ & $\mathrm{r}$ & $\mathrm{u}$ & u & $\mathrm{u}$ & 2 & 5 & 7 & 5 & 5 & 10 \\
\hline $\mathrm{u}$ & $r$ & $\mathrm{r}$ & $\mathbf{u} \quad \mathbf{v}$ & $\mathrm{u}$ & - & 1. & 1. & - & - & - \\
\hline $\mathrm{u}$ & $\mathrm{u}$ & $\mathrm{u}$ & $r \quad$ & $\mathbf{u}$ & - & - & - & - & 1 & 1. \\
\hline u. & $\mathrm{u}$ & $\mathrm{u}$ & $\mathrm{u}^{\mathrm{t}}$ & $\mathrm{u}$ & 14 & 1.2 & 26 & 27 & 18 & 45 \\
\hline $\mathrm{w}$ & $\mathrm{r}$ & $\mathrm{u}$ & $\mathrm{u} \quad \mathrm{u}$ & $\mathrm{u}$ & 5 & 3 & 8 & 2 & 3 & 5 \\
\hline $\mathrm{w}$ & $\mathrm{r}$ & $\mathrm{r}$ & $\mathrm{u} . \mathrm{t}$ & $\mathrm{u}$ & - & - & - & - & 1 & 1 \\
\hline $\mathrm{w}$ & $\mathrm{u}$ & $\mathrm{u}$ & $\mathrm{u} \quad \mathrm{v}$ & $\mathbf{u}$ & 3 & 8 & 11 & 4 & 7 & 1.1. \\
\hline $\mathrm{w}$ & $\mathrm{u}$ & a & $\mathrm{u} \quad \mathrm{u}$ & $\mathrm{u}$ & - & - & - & - & 1 & 1 \\
\hline $\mathrm{w}$ & $\mathrm{r}$ & $a$ & $\mathrm{u} \quad \mathrm{u}$ & $\mathrm{u}$ & - & - & - & 1 & - & 1. \\
\hline$w$ & a & u & $\mathrm{u} \quad \mathrm{v}$ & $\mathrm{u}$ & 1. & - & 1. & - & - & - \\
\hline $\mathrm{u}$ & w & $\mathrm{u}$ & $\mathrm{u} \quad \mathrm{u}$ & $\mathrm{u}$ & 1. & 2 & 3 & 2 & 5 & 7 \\
\hline $\mathrm{u}$ & $\mathrm{r}$ & $\mathrm{w}$ & $\mathrm{u} \quad \mathrm{u}$ & $\mathrm{u}$ & - & 1. & 1. & - & - & - \\
\hline $\mathrm{u}$ & $\mathrm{u}$ & $\mathrm{w}$ & $\mathrm{u} \quad \mathrm{u}$ & $\mathrm{u}$ & - & 1 & 1. & 1. & 2 & 3 \\
\hline $\mathrm{u}$ & $a$ & $a$ & w & $\mathrm{u}$ & 1. & - & 1 & - & - & - \\
\hline $\mathrm{u}$ & $\mathrm{r}$ & $a$ & $w$ & $\mathrm{u}$ & - & 1. & 1. & - & - & - \\
\hline $\mathrm{u}$ & $a$ & $\mathrm{u}$ & w & $\mathrm{u}$ & - & - & - & 1 & - & 1 \\
\hline u & $r$ & $\mathrm{ur}$ & $\mathrm{w}$ & $\mathrm{u}$ & - & 一 & - & 2 & 1. & 3 \\
\hline $\mathrm{u}$ & $\mathrm{u}$ & $\mathrm{r}$ & $w$ & $\mathrm{u}$ & - & 1. & 1. & - & - & - \\
\hline $\mathrm{u}$ & $\mathrm{u}$ & $\mathrm{u}$ & $\mathrm{w}$ & $\mathrm{u}$ & 6 & 2 & 8 & 3 & 6 & 9 \\
\hline $\mathrm{u}$ & $\mathrm{u}$ & $\mathrm{u}$ & $\mathrm{u}$ & $\mathrm{w}$ & - & - & - & 3 & 1. & 4 \\
\hline $\mathrm{w}$ & $w$ & $\mathrm{u}$ & $\mathrm{u}$ & $\mathrm{u}$ & 1 & 2 & 3 & 3 & 3 & 6 \\
\hline$w$ & $\mathrm{w}$ & $\mathrm{r}$ & $\mathrm{u}$ & $\mathbf{u}$ & - & 1. & 1. & - & - & - \\
\hline w & $r$ & $\mathrm{u}$ & $\mathrm{w}$ & $\mathrm{u}$ & 3 & - & 3 & 1. & 1. & 2 \\
\hline$w$ & $\mathrm{u}$ & $\mathrm{u}$ & $\mathrm{w}$ & $\mathrm{u}$ & 7 & 4 & 11. & 3 & 1. & 4 \\
\hline w & $\mathrm{u}$ & $\mathrm{w}$. & $\mathrm{u}$ & $\mathbf{u}$ & - & - & - & 1 & 1. & 2 \\
\hline
\end{tabular}




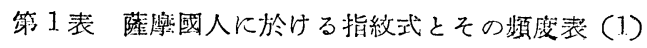

\begin{tabular}{|c|c|c|c|c|c|c|}
\hline \multirow{2}{*}{ 指繳式侧 } & \multicolumn{3}{|c|}{$\sigma^{\circ}$} & \multicolumn{3}{|c|}{ 웅 } \\
\hline & $\mathrm{r}$ & 1 & $r+1$ & $\mathrm{r}$ & 1 & $\mathrm{r}+1$ \\
\hline$a \quad w \quad u \quad w \quad u$ & 1. & - & 1 & - & - & - \\
\hline $\begin{array}{lllll} & \mathrm{w} & \mathrm{u} & \mathrm{w} & \mathrm{u}\end{array}$ & 3 & 1 & 4 & 5 & - & 5 \\
\hline $\begin{array}{lllll} & \mathrm{w} & \mathrm{r} & \mathrm{w} & \mathrm{u}\end{array}$ & - & 1 & 1. & - & 一 & - \\
\hline 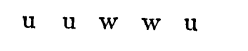 & 1 & 1. & 2 & - & 2 & 2 \\
\hline 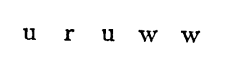 & - & - & - & - & 1. & 1 \\
\hline 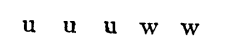 & 3 & 2 & 5 & 5 & 2 & 7 \\
\hline w w w u u & 2 & 2 & 4 & - & 5 & 5 \\
\hline 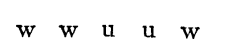 & 1. & - & 1 & - & 2 & 2 \\
\hline 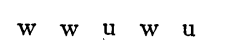 & 4 & 4 & 8 & 4 & 6 & 10 \\
\hline $\mathrm{w} \quad \mathrm{u} \quad \mathrm{w} \quad \mathrm{w} u$ & 2 & 2 & 4 & 1. & 1 & 2 \\
\hline$w \quad u \quad u \quad w$ & 1 & 2 & 3 & - & 1. & 1. \\
\hline$a w w u$ & - & 1. & 1. & - & - & - \\
\hline $\mathrm{u} \quad \mathrm{w} w \mathrm{w} u$ & 1 & 4 & 5 & 3 & 5 & 8 \\
\hline $\mathrm{u} \quad \mathrm{w} \quad \mathrm{u} \quad \mathrm{w} \quad \mathrm{w}$ & 1. & - & 1. & 1. & - & 1. \\
\hline $\begin{array}{lllll}\mathrm{u} & \mathrm{r} & \mathrm{w} & \mathrm{w} & \mathrm{w}\end{array}$ & 1. & - & 1. & 1. & - & 1. \\
\hline $\mathrm{u} \quad \mathrm{u} \quad \mathrm{w}^{\mathrm{w}} \quad \mathrm{w} \quad \mathrm{w}$ & - & 2 & 2 & - & 1. & 1. \\
\hline $\mathrm{w} \quad \mathrm{w} \quad \mathrm{w} \quad \mathrm{w}$ & 8 & 9 & 17 & 6 & 8 & 14 \\
\hline 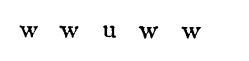 & 2 & 3 & 5 & 8 & - & 8 \\
\hline 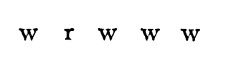 & 1 & 1. & 2 & - & 1. & 1. \\
\hline $\mathrm{w} \quad \mathrm{u} \quad \mathrm{w} \quad \mathrm{w} \quad \mathrm{w}$ & 1. & 2 & 3 & 1. & 1. & 2 \\
\hline u $\quad$ w $\quad w \quad w \quad w$ & 3 & 2 & 5 & 2 & 3 & 5 \\
\hline $\mathrm{w} \quad \mathrm{w} \quad \mathrm{w} \quad \mathrm{w} \quad \mathrm{w}$ & 23 & 1.8 & 41. & 11. & 9 & 20 \\
\hline 命 & 1.03 & 1.03 & 206 & 108 & 1.08 & 216 \\
\hline
\end{tabular}




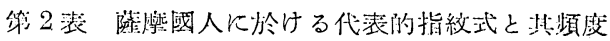

\begin{tabular}{rr|r|r|r|r|r|r|r}
\hline \hline \\
\hline \hline
\end{tabular}

䈞 3 裴 w w w w w 及び u u u u u 䪷度比較衰 (\%士m\%)

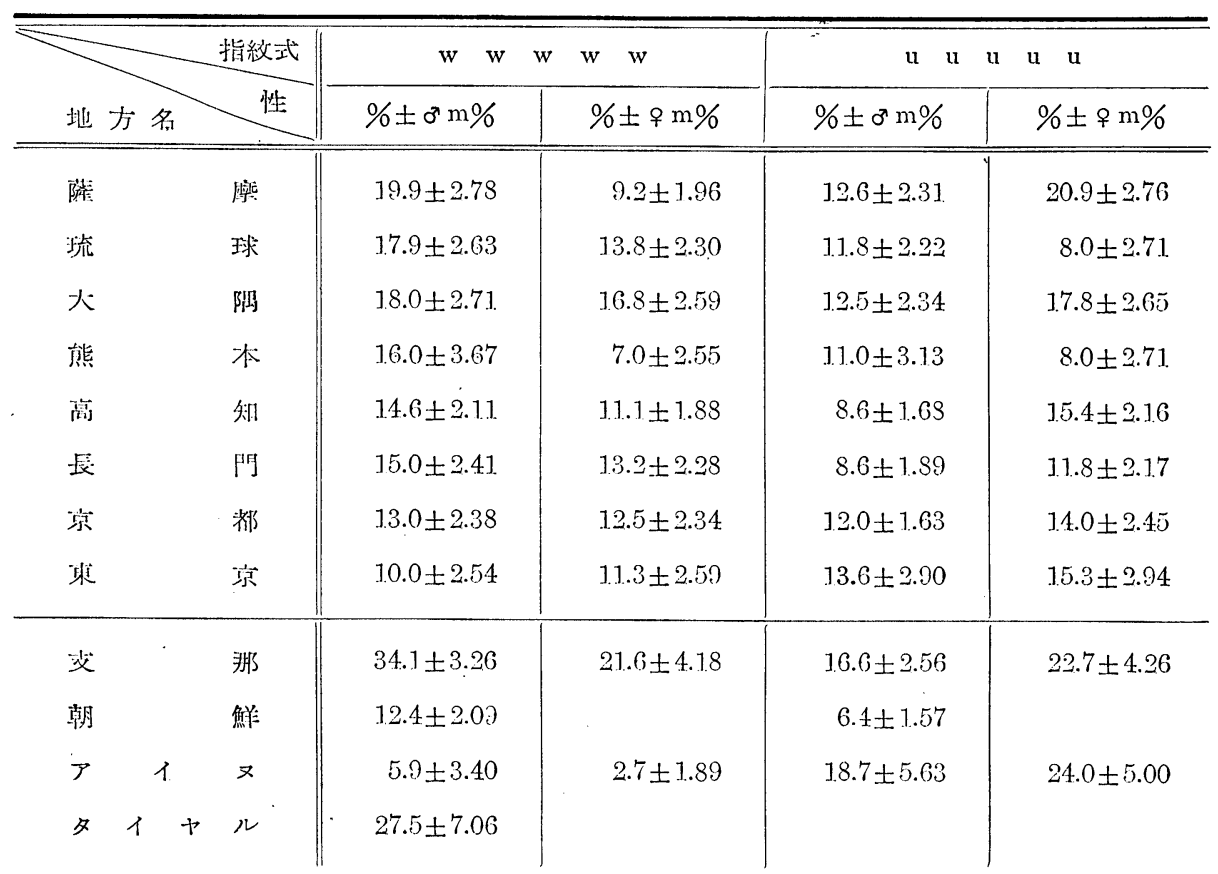




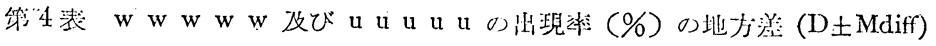

(陸磨國人一他地方人)

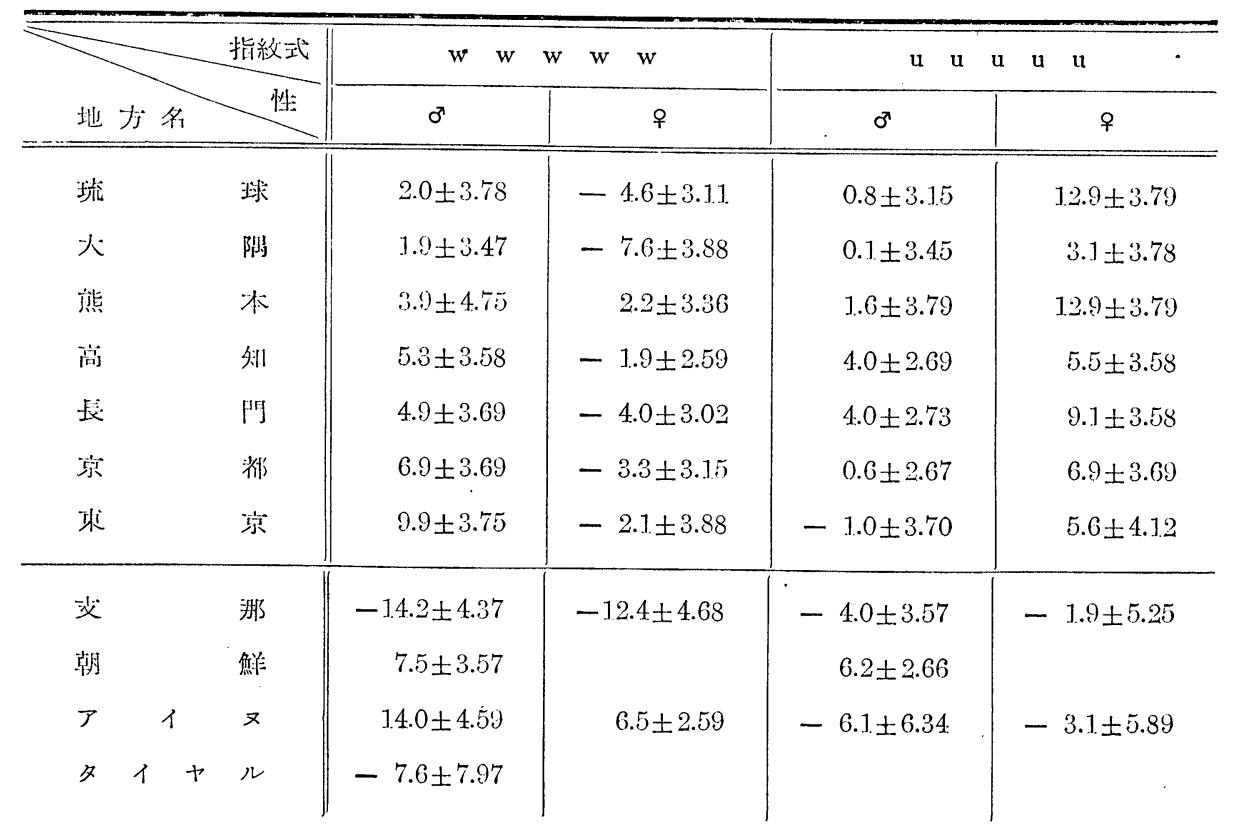

$\mathrm{W} \mathrm{W} \mathrm{W} \mathrm{W} \mathrm{W} \mathrm{と} \mathrm{u} u$ u u u との頻度を比較すると琞性にありては著差がないが女性 そありては $\mathrm{u}$ u u u u の頻度稍高い偭向がある。

次に W W w w W 及び u u u u u 就て他地方人及び周圍諸人種のそれと比較 すると第 3 裴、第 4 裴の如くなる。

即ち以上の成續に低ると薩摩人の $\mathrm{w} \mathrm{w} . \mathrm{w} \mathrm{w}$ w の頻度は男性にありては比較地方 人中最高であるが女性に於ては最も低位にあり、男性にては大隅人琉球人に近いが他 地方人とは著等がない。然し支那人種とは確答を認める。女性にありては高知人東京 人に近い關係を示すが他地方人及他人稞之の間に著美を見ない。

次に薩摩人に於ける $\mathrm{u} u \mathrm{u} u \mathrm{u}$ の頻度は男女性其に他地方人に比し高位にあり男 性にありては大隅人、京都人及び琉球人に近いが其他地方人並に周園人種間に著茫が 然い。女性にありては大隅人に近いが琉球人熊本人をは確老があり、支那人とも近い 韭係を示す。

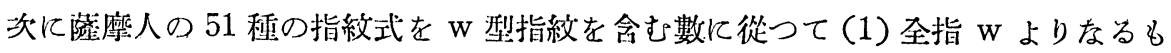
の、（2） 4 指に wを佮するもの、(3) 3 指に w を伤するもの、(4) 2 指に w を侍する 
もの、(5) 1 指に w を有するもの、(6)全指に w を有せざるものの 6 型に分類して其 頻度を求めると第 5 裴の如くなる。

第 5 表 薩恢國人に於ける $\mathrm{w}$ 型指紋數による指紋式分類表

\begin{tabular}{|c|c|c|c|c|c|c|}
\hline 性 & \multicolumn{3}{|c|}{$\sigma^{*}$} & \multicolumn{3}{|c|}{ q. } \\
\hline $\mathrm{w}$ 犁指紋式 侧 & $r$ & 1 & $r+1$ & $x$ & 1 & $\mathrm{r}+1$ \\
\hline (1) $\mathrm{w}_{5}$ & 23 & 1.8 & 41. & 11. & 9 & 20 \\
\hline (2) 5 指饾 $\mathrm{w}_{4} \sigma$ も & 15 & 17 & 32 & 17 & 19 & 30 \\
\hline (3) 5 指内 & 13 & 17 & 30 & 10 & 21. & 31. \\
\hline$(1)+(2)+(3)$ & 51. & 52 & 1.03 & 38 & 43 & 81 \\
\hline$(\% \pm m \%)$ & $(49.5 \pm 4.92)$ & $(50.5 \pm 4.92)$ & $(50.0 \pm 3.48)$ & $(35.2 \pm 4.60)$ & $(39.8 \pm 4.70)$ & $(37.5 \pm 3.22)$ \\
\hline (4) 5 指中 $\mathrm{w}_{2}$ の \& & 19 & 12 & 31. & 1.8 & 11. & 29 \\
\hline (5) 5 指中 $\mathrm{w}_{1}$ のも & 17 & 19 & 36 & 19 & 27 & 46 \\
\hline （6）5指にwを缺くもの & 16 & 29 & 36 & 33 & 27 & 60 \\
\hline$(4)+(5)+(6)$ & 52 & 51. & 103 & $70^{\circ}$ & 65 & 195 \\
\hline$(\% \pm m \%)$ & $(50.5 \pm 4.92)$ & $(49.5 \pm 4.92)$ & $(50.0 \pm 3.48)$ & $(64.8 \pm 4.60)$ & $|(60.2 \pm 4.70)|$ & $(62.5 \pm 3.22)$ \\
\hline
\end{tabular}

以上の成䋶に就て觀るに 3 指以上に $\mathrm{w}$ を付する指紋式と 3 指以上に之を缺くもの

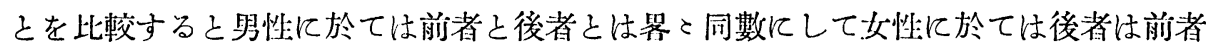
より多い。更に之を性别に比較すると前者に於ては男性に多く後者に於ては女性に多 い。丈左右別に就て見ると网者に著しい粪異を認めない。

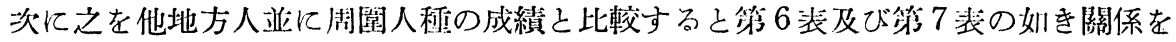
示す。

萨摩人の 3 指以上飞指紋を付する頻度は略性にありては高知人に最も近似し义琉球

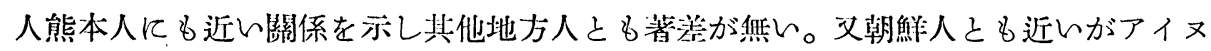

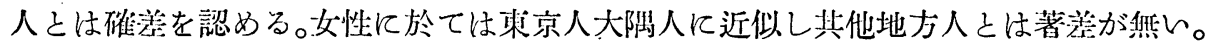
然しアイヌ人とは確差がある。丈 3 指以上に $\mathrm{w}$ を缺くものの頻度は男性に於ては。 高知人と最も近く次で琉球人とも近い關係を示し、叉朝鮮人とも同數であるがアイヌ 人とは確兴がある。女性に於ては東京人琉球人证びに大隅人等に近く、其他地方人之 も著美がない。然しアイヌ人種とは確差を示す。 
第 6 表 $3 \mathrm{w}$ 以:上及び $3 \mathrm{w}$ 以下の指紋式頻度比較表

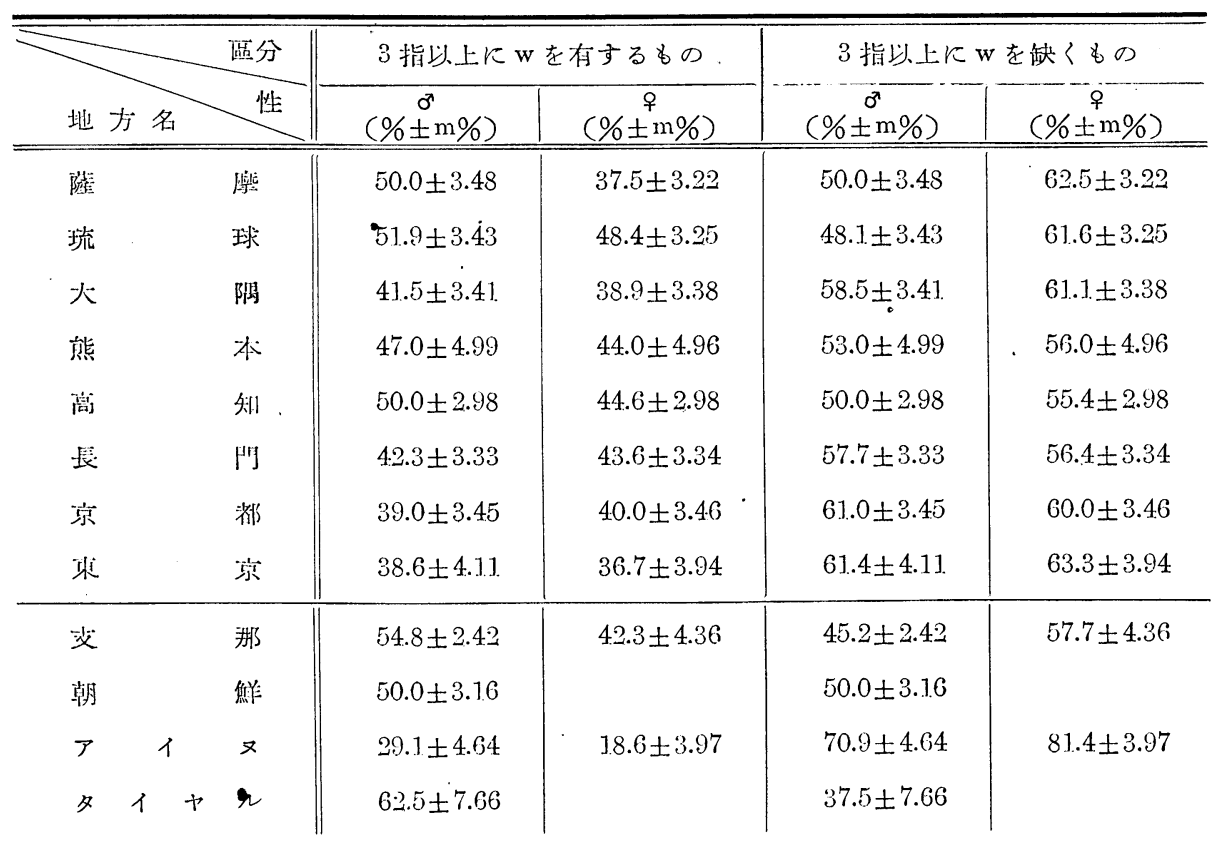

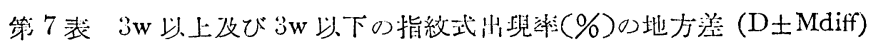

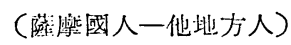

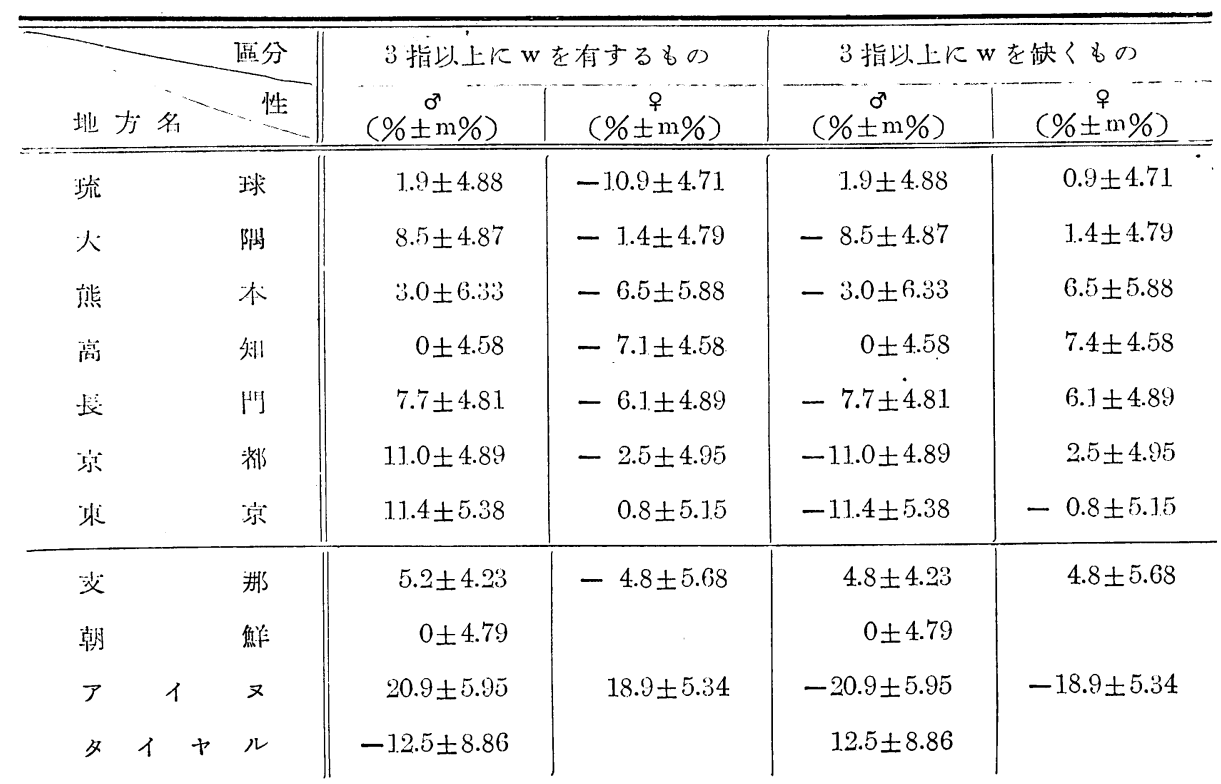




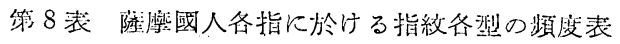

\begin{tabular}{|c|c|c|c|c|c|c|c|}
\hline \multirow{2}{*}{$\begin{array}{l}\text { 指 } \\
\text { 紋 } \\
\text { 然! }\end{array}$} & \multirow[b]{2}{*}{ 指侧 } & \multicolumn{3}{|c|}{$0^{7}$} & \multicolumn{3}{|c|}{ q } \\
\hline & & $\mathrm{r}$ & 1 & $r+1$ & $\mathrm{r}$ & 1 & $\mathrm{r}+1$ \\
\hline \multirow{6}{*}{$\mathrm{a}$} & I & 1. & 2 & 3 & 1 & 3 & 4 \\
\hline & II & 2 & 1. & 3 & 1 & - & 1 \\
\hline & III & 1. & 2 & 3 & J. & 1. & 2 \\
\hline & IV & - & - & - & 1. & - & 1. \\
\hline & $\mathrm{V}$ & - & - & - & 1. & - & 1. \\
\hline & $\mathrm{I}-\mathrm{V}$ & 4 & 5 & 9 & 5 & 4 & 9 \\
\hline \multirow{6}{*}{$\mathrm{r}$} & I & - & - & - & - & - & - \\
\hline & II & 1.2 & 1.2 & 24 & 1.2 & 1.3 & 25 \\
\hline & III & - & 4 & 4 & - & 1 & 1. \\
\hline & IV & - & - & - & - & 1. & 1. \\
\hline & $\mathrm{V}$ & - & - & - & - & - & - \\
\hline & $\mathrm{I}-\mathrm{V}$ & 12 & 1.6 & 28 & 1.2 & 1.5 & 27 \\
\hline \multirow{6}{*}{$\mathrm{u}$} & $\mathrm{I}$ & 37 & 40 & 77 & 61. & 53 & 11.4 \\
\hline & II & 38 & 40 & 78 & 50 & 4.7 & 99 \\
\hline & III & 59 & 51. & 1.10 & 80 & 67 & 147 \\
\hline & IV & 30 & 40 & 70 & 49 & 57 & 106 \\
\hline & V & 66 & 7.1. & 137 & 75 & 86 & 161. \\
\hline & $\mathrm{I}-\mathrm{V}$ & 230 & 242 & 472 & 315 & 312 & 627 \\
\hline \multirow{6}{*}{$\mathrm{w}$} & I & 65 & 61. & 126 & 46 & 52 & 98 \\
\hline & II & 51. & 50 & 101. & 45 & 46 & 91. \\
\hline & III & 43 & 46 & 89 & 27 & 39 & 66 \\
\hline & IV & 73 & 63 & 1.36 & 58 & 50 & 1.08 \\
\hline & V & 37 & 32 & 69 & 32 & 22 & 54 \\
\hline & $\mathrm{I}-\mathrm{V}$ & 269 & 252 & 521. & 208 & 209 & 417 \\
\hline 合 & it & .51 .5 & 515 & 1.030 & 540 & 540 & 1080 \\
\hline
\end{tabular}


次に薩摩人指肚に於ける $\mathrm{a}, \mathrm{r}, \mathrm{n}, \mathrm{w}$ 等 4 型指紋の頻度を各指に就て示すを第 8 裴 を得る。a 型指紋は男性に於ては I, II, III 指のみに現はれ女性では不側は各指に应 側は I III 指のみに現はれる。 $\mathrm{r}$ 型指紋は舅性では右側 II 指のみ左側 II, III 指のみ に現はれ女性では右側 II 指にのみ庄側 II, III 指のみに現はれる。次に u 型指紋は III, V 指に多く, w 型指紋は IV, I, II 指に多く現はれんとする倾向がある。 次に薩摩人の 4 型指紋の全指數に對する頻度を調夜すると第 9 裴を得る。

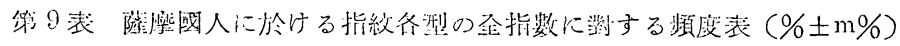

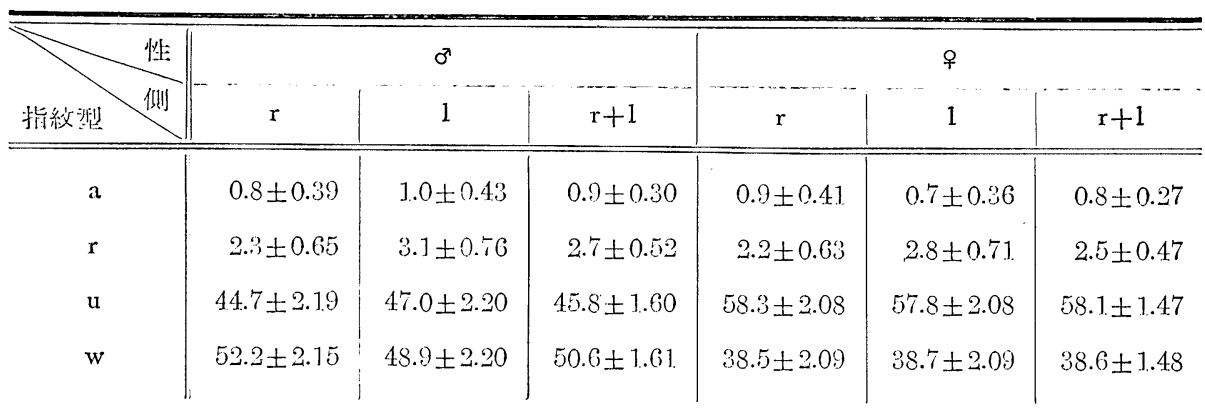

即ち薩摩人に於ける指紋にありては兩性洪に u 型及び $\mathrm{w}$ 型指紋の頻度最も大で $\mathrm{a}$

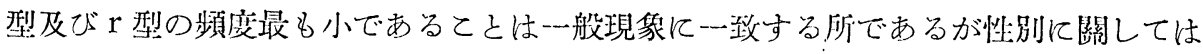
$\mathrm{u}$ 型は女性に w 型は男性に多い倾向がある、庄在別は著等を認め難い。

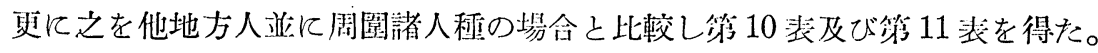

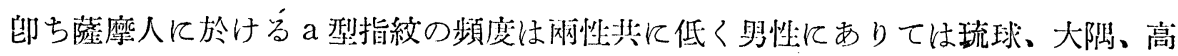
知人に近く京都人とは著觉がある、メアイメ人種とも碓等を認める。女性にありては

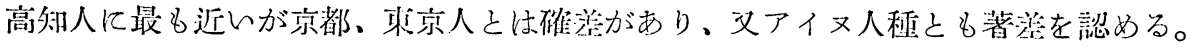
$\mathrm{r}$ 型指紋も亦其頻度网性基低くして男性に於ては高知人子同數であつて其他地方人

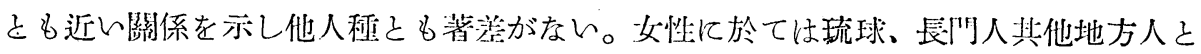
の間任殆ど磨を見ない、そして朝然人種とは同数を示し文那、アイヌ人種とも近い關 係が認められる。u型指紋は男性にありては高知、熊本及び琉球人に近く東京人とは

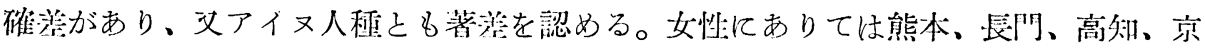
都人との間に著学があり、文朝鮮人種とも確然を認める。W型指紋は男性に於ては高 知人最も近く、次で琉球、熊本人に近似するが京都柬京人とは著筷を認め、又朝鮮人

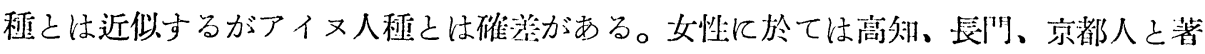


494

三 浦 正 義

第 10 表 指紋各型の頻度比較表 $(\% \pm m \%)$

\begin{tabular}{|c|c|c|c|c|c|}
\hline 地方名 & 性 & a & $\mathbf{r}$ & $\mathrm{u}$ & $\mathrm{w}$ \\
\hline 墔 & $\begin{array}{l}0^{7} \\
+\end{array}$ & $\begin{array}{l}0.9 \pm 0.30 \\
0.8 \pm 0.27\end{array}$ & $\begin{array}{l}2.7 \pm 0.52 \\
2.5 \pm 0.47\end{array}$ & $\begin{array}{l}45.8 \pm 1.60 \\
58.1 \pm 1.47\end{array}$ & $\begin{array}{l}50.6 \pm 1.61 \\
38.6 \pm 1.48\end{array}$ \\
\hline 琉 & $\begin{array}{l}0^{7} \\
+9\end{array}$ & $\begin{array}{l}1.1 \pm 0.32 \\
2.5 \pm 0.47\end{array}$ & $\begin{array}{l}2.1 \pm 0.44 \\
2.9 \pm 0.50\end{array}$ & $\begin{array}{l}44.8 \pm 1.53 \\
53.7 \pm 1.19\end{array}$ & $\begin{array}{l}51.9 \pm 1.53 \\
40.8 \pm 1.47\end{array}$ \\
\hline 大 & $\begin{array}{l}0 \\
+9\end{array}$ & $\begin{array}{l}1.2 \pm 0.34 \\
2.1 \pm 0.45\end{array}$ & $\begin{array}{l}3.3 \pm 0.56 \\
3.1 \pm 0.54\end{array}$ & $\begin{array}{l}50.5 \pm 1.58 \\
52.6 \pm 1.59\end{array}$ & $\begin{array}{l}45.0 \pm 1.56 \\
42.2 \pm 1.56\end{array}$ \\
\hline 㘳 & $\begin{array}{l}0 \\
9\end{array}$ & $\begin{array}{l}3.6 \pm 0.83 \\
6.8 \pm 1.13\end{array}$ & $\begin{array}{l}2.4 \pm 0.68 \\
1.6 \pm 0.56\end{array}$ & $\begin{array}{l}45.2 \pm 2.23 \\
49.2 \pm 2.24\end{array}$ & $\begin{array}{l}48.6 \pm 2.24 \\
42.2 \pm 2.21\end{array}$ \\
\hline 高 & $\begin{array}{l}0^{7} \\
\text { 우 }\end{array}$ & $\begin{array}{l}1.3 \pm 0.30 \\
0.2 \pm 0.12\end{array}$ & $\begin{array}{l}2.7 \pm 0.43 \\
3.1 \pm 0.46\end{array}$ & $\begin{array}{l}46.2 \pm 1.33 \\
51.1 \pm 1.33\end{array}$ & $\begin{array}{l}49.7 \pm 1.34 \\
4.5 .5 \pm 1.33\end{array}$ \\
\hline 長 & $\begin{array}{l}0^{\circ} \\
\text { 우 }\end{array}$ & $\begin{array}{l}2.4 \pm 0.46 \\
1.5 \pm 0.37\end{array}$ & $\begin{array}{l}3.7 \pm 0.57 \\
2.1 \pm 0.43\end{array}$ & $\begin{array}{l}48.7 \pm 1.51 \\
50.9 \pm 1.51\end{array}$ & $\begin{array}{l}45.2 \pm 1.50 \\
45.5 \pm 1.50\end{array}$ \\
\hline 宗 & $\begin{array}{l}\sigma^{x} \\
\delta\end{array}$ & $\begin{array}{l}5.5 \pm 0.72 \\
4.3 \pm 0.64\end{array}$ & $\begin{array}{l}3.4 \pm 0.57 \\
3.0 \pm 0.54\end{array}$ & $\begin{array}{l}49.4 \pm 1.58 \\
50.6 \pm 1.58\end{array}$ & $\begin{array}{l}41.7 \pm 1.55 \\
42.1 \pm 1.56\end{array}$ \\
\hline 页 & $\begin{array}{l}0^{2} \\
0\end{array}$ & $\begin{array}{l}2.9 \pm 0.63 \\
4.1 \pm 0.7 .2\end{array}$ & $\begin{array}{l}3.6 \pm 0.50 \\
3.3 \pm 0.65\end{array}$ & $\begin{array}{l}52.7 \pm 1.89 \\
52.1 \pm 1.82\end{array}$ & $\begin{array}{l}40.9 \pm 1.86 \\
40.4 \pm 1.79\end{array}$ \\
\hline 沙 & $\begin{array}{l}0^{2} \\
+9\end{array}$ & $\begin{array}{l}1.9 \pm 0.29 \\
2.4 \pm 0.49\end{array}$ & $\begin{array}{l}2.9 \pm 0.36 \\
2.4 \pm 0.49\end{array}$ & $\begin{array}{l}42.7 \pm 1.07 \\
51.0 \pm 1.60\end{array}$ & $\begin{array}{l}52.5 \pm 1.03 \\
53.4 \pm 1.60\end{array}$ \\
\hline 胡 & $\begin{array}{l}0^{\circ} \\
+9\end{array}$ & $\begin{array}{l}2.8 \pm 0.46 \\
4.1 \pm 0.26\end{array}$ & $\begin{array}{l}4.0 \pm 0.55 \\
2.5 \pm 0.22\end{array}$ & $\begin{array}{l}43.1 \pm 1.40 \\
46.8 \pm 0.69\end{array}$ & $\begin{array}{l}50.1 \pm 1.41 \\
49.4 \pm 0.69\end{array}$ \\
\hline$ア \quad 1$ & $\begin{array}{l}0^{\top} \\
+9\end{array}$ & $\begin{array}{l}5.4 \pm 1.03 \\
7.5 \pm 0.97\end{array}$ & $\begin{array}{l}2.7 \pm 0.86 \\
2.3 \pm 0.55\end{array}$ & $\begin{array}{l}60.0 \pm 2.24 \\
67.6 \pm 1.73\end{array}$ & $\begin{array}{l}31.9 \pm 2.13 \\
22.6 \pm 1.55\end{array}$ \\
\hline タイヤル & $\begin{array}{l}0^{\circ} \\
9\end{array}$ & $2.0 \pm 0.99$ & $2.0 \pm 0.99$ & $33.5 \pm 3.34$ & $61.5 \pm 3.44$ \\
\hline
\end{tabular}




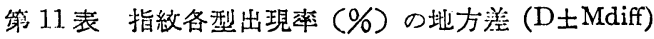

（酸摩國人一他地方人)

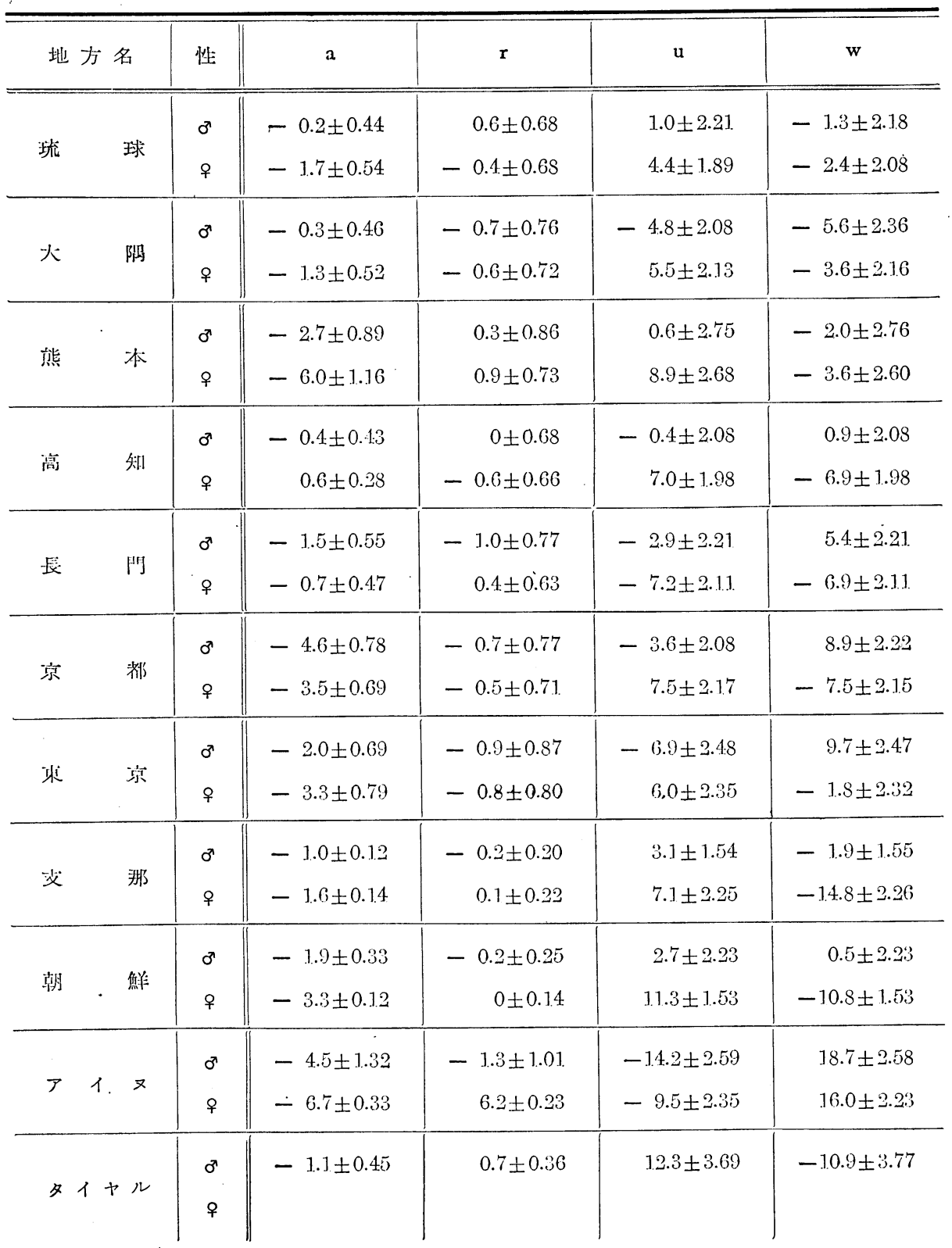


婊があり、周图䍀人種とる夫及猚美を認める。

次に蒢摩人に就て $\mathrm{w}$ 型指紋中二重及び双胎蹄係紋の $\mathrm{w}$ 型指紋に對する出現頻度を 示せば第 12 㛙の如くなる。

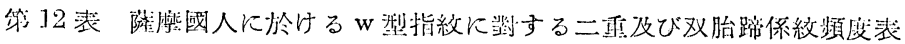

\begin{tabular}{|c|c|c|c|c|c|c|}
\hline \multirow[b]{2}{*}{ 指 } & \multicolumn{3}{|c|}{$\sigma^{\circ}$} & \multicolumn{3}{|c|}{ ㅇ․ } \\
\hline & $\begin{array}{ll}\mathrm{r} \\
\mathrm{w} & \mathrm{D}+\mathrm{Z} \\
\end{array}$ & $\mathrm{w} \cdot \mathrm{I} D+\mathrm{Z}$ & $w \quad \begin{array}{r}r+1 \\
D+Z\end{array}$ & $\mathrm{w} \quad \mathrm{r}+\mathrm{D}+\mathrm{Z}$ & $\mathrm{w} \quad \mathrm{D}+\mathrm{Z}$ & $\begin{array}{r}r+1 \\
w^{r} \quad \mathrm{I}+\mathrm{Z} \\
\end{array}$ \\
\hline I & $\begin{array}{c}65 \quad 10 \\
(1.5 .4 \pm 4.46)\end{array}$ & $\begin{array}{c}61 . \\
(26.2 \pm 5.48)\end{array}$ & $\begin{array}{l}126 \quad 26 \\
(30.6 \pm 3.60)\end{array}$ & $\begin{array}{c}46 \quad 11 \\
(23.8 \pm 6.28)\end{array}$ & $\begin{array}{cc}52 & 23 \\
(44.2 \pm 6.89)\end{array}$ & $\begin{array}{c}98 \\
(34.7 \pm 4.81)\end{array}$ \\
\hline II & $\begin{array}{c}51 . \quad 6 \\
(11.7 \pm 4.43) \\
\end{array}$ & $\begin{array}{c}50 \\
(16.0 \pm 5.18)\end{array}$ & $\begin{array}{l}1.01 . \quad 14 \\
(1.3 .8 \pm 3.33)\end{array}$ & $\begin{array}{c}45 \quad 7 \\
(15.5 \pm 5.39)\end{array}$ & $\begin{array}{cc}46 & 8 \\
(17.4 \pm 5.59)\end{array}$ & $\begin{array}{c}91 \quad 15 \\
(17.6 \pm 3.99)\end{array}$ \\
\hline III & $\begin{array}{l}4.3 \quad 3 \\
(7.0 \pm 3.88)\end{array}$ & $\begin{array}{c}46 \\
(19.5 \pm 5.86)\end{array}$ & \begin{tabular}{cc}
89 & 12 \\
$(13.5 \pm 3.52)$ \\
\multicolumn{2}{c}{} \\
\end{tabular} & $\begin{array}{c}27 \\
\text { (1.1.1 } \pm 4.63)\end{array}$ & $\begin{array}{c}39 \quad 11 \\
(28.2 \pm 7.61)\end{array}$ & $\begin{array}{c}66 \quad 14 \\
(21.2 \pm 5.03) \\
\end{array}$ \\
\hline IV & $\begin{array}{l}73 \quad 1 . \\
(1.3 \pm 1.32)\end{array}$ & $\begin{array}{l}63.1 . \\
(1.6 \pm 1.58)\end{array}$ & $\begin{array}{l}136 \quad 2 \\
(1.5 \pm 1.04)\end{array}$ & $\begin{array}{l}58 \quad 2 \\
(3.4 \pm 2.36)\end{array}$ & $\begin{array}{l}50 \quad 3 \\
(6.0 \pm 3.34)\end{array}$ & $\begin{array}{l}108 \quad 5 \\
(4.6 \pm 2.01)\end{array}$ \\
\hline $\mathrm{V}$ & $\begin{array}{l}37 \quad 1 \\
(2.7 \pm 2.66)\end{array}$ & $\begin{array}{l}32 \quad 3 \\
(9.4 \pm 5.35)\end{array}$ & $\begin{array}{l}69 \quad 4 \\
(5.8 \pm 2.81)\end{array}$ & $\begin{array}{l}32 \quad 1 \\
(3.1 \pm 3.06)\end{array}$ & $\begin{array}{cc}22 & 4 \\
(18.1 \pm 8.21)\end{array}$ & $\begin{array}{l}54 \quad 5 \\
(9.2 \pm 3.93)\end{array}$ \\
\hline $\mathrm{I}-\mathrm{V}$ & $\begin{array}{l}269 \quad 21 \\
(7.8 \pm 1.63)\end{array}$ & $\begin{array}{l}252 \quad 37 \\
(14.6 \pm 2.16)\end{array}$ & $\begin{array}{l}521.58 \\
(11.1 \pm 1.37)\end{array}$ & $\begin{array}{l}208 \quad 24 \\
(1.1 .5 \pm 2.21)\end{array}$ & $\begin{array}{l}209 \\
(23.4 \pm 2.86)\end{array}$ & $\begin{array}{l}417 \quad 73 \\
(17.4 \pm 1.80)\end{array}$ \\
\hline
\end{tabular}

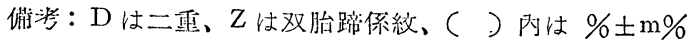

即ち $\mathrm{w}$ 型指紋に對する二重及び双胎蹄係紋の出現率は网性共に I 指最も多く IV 指最も少い。全指合計より觀れば女性は男性より秒多い。左右等は网性共に左側に多 n。

次に薩摩大と他地方人と比較すると第 13 裴及び第 14 表の如くなる。

郘ち薩摩人の $\mathrm{w}$ 型指紋に對する二重及び双胎蹄係紋の出現率は男性に於ては柬京 人に近いが高知、大隅、長門人とは著铚があり、女性に於ては琉球人長鬥人に近く其 他地方人とは著层が無い。 


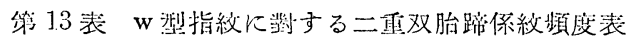

\begin{tabular}{|c|c|c|c|c|c|c|c|}
\hline \multirow{2}{*}{\multicolumn{2}{|c|}{ 地方名 }} & \multicolumn{3}{|c|}{$0^{7}$} & \multicolumn{3}{|c|}{$\dot{\phi}$} \\
\hline & & w 型 & $\mathrm{D}+\mathrm{Z}$ & $\% \pm \mathrm{m} \%$ & $\mathrm{w}$ 型 & $D+Z$ & $\% \pm m \%$ \\
\hline 篧 & 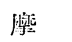 & 521. & 58 & $11.1 \pm 1.37$ & 417 & 73 & $17.4 \pm 1.80$ \\
\hline 琉 & 球 & 550 & 97 & $17.6 \pm 1.62$ & $44: 8$ & 74 & $16.5 \pm 1.75$ \\
\hline 火 & ·隅 & 450 & 98 & $21.8 \pm 1.94$ & 439 & 60 & $1.3 .6 \pm 1.63$ \\
\hline 高 & 知 & 697 & $15 f$ & $22.4 \pm 1.58$ & 638 & 143 & $22.4 \pm 1.65$ \\
\hline 長 & 邽 & 4.97 & $9 \ddot{0}$ & $19.1 \pm 1.76$ & 500 & 81. & $16.2 \pm 1.65$ \\
\hline 宗 & 柈 & 417 & 33 & $7.9 \pm 1.32$ & 421. & 51. & $12.1 \pm 1.59$ \\
\hline 東 & 宗 & 286 & 31. & $10.8 \pm 1.82$ & 303 & 40 & $13.2 \pm 1.94$ \\
\hline
\end{tabular}

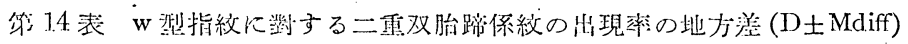

(陆整國人一他地方人)

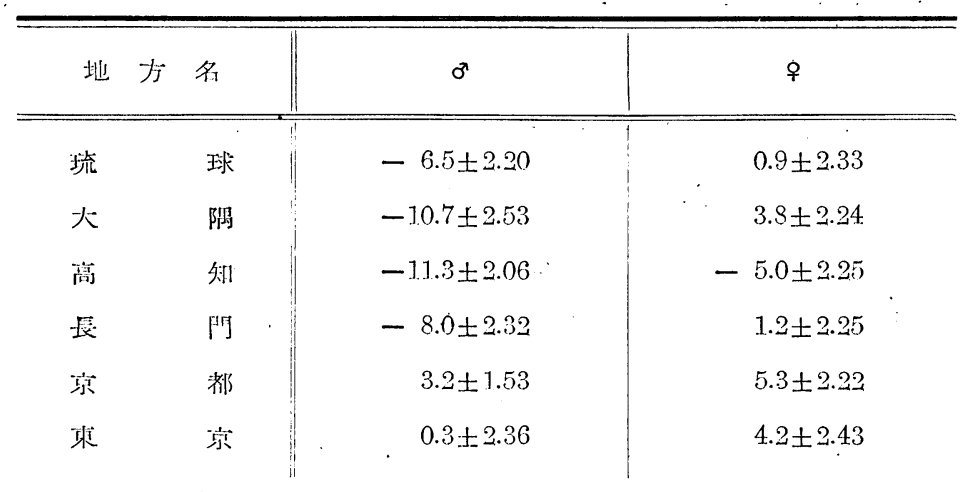

第三章，結

薩摩國人男 103 人、女 108 人合計 422 手飞就て指紋を調查し二次の絬果を得た。

（1）薩摩國人の指紋式绀男 40 種、女 39 種、中男女共通なるもの 28 種、男女總計 51 種である。

（2）出現頻度の高い代表的指紋式としては男性 W w w w w $(19.9 \% \pm 2.78 \%), \mathrm{u} \mathrm{u} \mathrm{u}$ u u $(12.9 \% \pm 2.31 \%)$, w w w w u $(8.2 \% \pm 1.91 \%)$, 女性 u u u u u $(20.9 \% \pm 2.76 \%)$, $\mathrm{W}$ W $\mathrm{W}$ W w $(9.2 \% \pm 1.96 \%), \mathrm{w}$ W w w u $(6.5 \% \pm 1.67 \%)$ 等である。

（3） 3 指以上飞 W を倠する指紋式の出現率は男性 $(50.0 \% \pm 3.48 \%)$, 女性 $(37.5 \% \pm$ $3.22 \%)$ にして 3 指以上にWを缺くものは男性 (50.0\% $\pm 3.48 \%)$ ，女性 $(62.5 \% \pm 3.22 \%)$ 
である。

（4）各型指紋中 $u$ 型：男性 $(45.8 \% \pm 1.60 \%)$ ，女性 $(58.1 \% \pm 1.47 \%), w$ 型：男性 $(50.6 \% \pm 1.61 \%)$ ，女性 $(38.6 \% \pm 1.48 \%)$ の頻度最も大にして a 型：男性 $(0.9 \% \pm$ $0.30 \%)$, 女性 $(0.8 \% \pm 0.27 \%), \mathrm{r}$ 型：男性 $(2.7 \% \pm 0.52 \%)$, 女性 $(2.5 \% \pm 0.47 \%)$ の 頻度最も小である。

（5）各型指紋出現頻度の左右別に關しては著差がないが性别に關しては 型は女性に $\mathrm{w}$ 型は男性に多く現はれんとする偭向がある。

（6） $\mathrm{w}$ 型指紋飞 對する二重及び 双胎蹄係紋の出現率恃男性 $(11.1 \% \pm 1.37 \%)$ ，女性 $(17.4 \% \pm 1.80 \%)$ であつて网性共に拇指に最も多く環指に最も少い。女性は男性より 稍多く、龙側は右側より多い。

（7）薩摩人の指紋を周園地方人と比較するに琉球人と最も接近し、大隅人とも大差な く次で高知人、熊本人とも相似た閵係を示す。

（8）周圍諸人種と比較するに朝鮮人とは稍近い傾向があるがアイメ人とは最も隔りが あり贋こ確差を現はす。

（9）以上の成續は余の大隅國人に就いての前報告之殆ぞ同一であり且つ三宅宗筧氏の 手掌理紋の研究に於て薩摩人は琉球人大隅人之近几關係にありとの報告とは全く一致 し、てれ等西南諸地方人が相似を體質を有する事を知り得た。

擱箁に際し三宅講師の御指導並びに御校閱と中山英司氏の御援助に對し深く感謝の 意を表す。(炤和 14 年 3 月)
主 要 文
1. 金關文头：流球人の人類學的研觉
人類學新誌第 45 卷第 5 號 1930.
2. 同

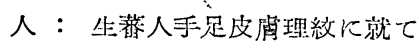
3. 岸桑自直樹：アイヌ指紋の研究
4. 忽那 將要：日本人手掌理紋の研然
人類學雜誌第 44 卷第 11.12 號 1929.
十全會新誌第 40 姿第 7 號 1935.
5. 三宅宗悅：大䧈國传民の手掌理紋の研茫
人類學新誌笴 46 爸第 8 附錄 1.931.
6. 同
人：限麻國住民の手掌理紋の研究
7. 吉見恒雄: 長門國人指紋の破究
人数學雜誌第 52 替第 1 號 1937.
人類學新誈第 51 爸第 12 號 1.936.
8. 三宅秀夫：朝鮮人ノ手理紋

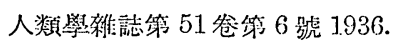
9. 椎野﨧太郎: 交那人ノ手理紋
10. 鹳波光重：土佐人手掌理紋の砄究

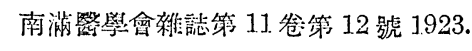
11. 三浦正㼁：大䧓國人指紋の研梦 南㴖醫學會辣誌第 11 卷第 7 號 1923. 人類學雜誌第 51 爸第 1.0 號 1.936. 人類學雜誌第 54 爸第 5 號 1939. 